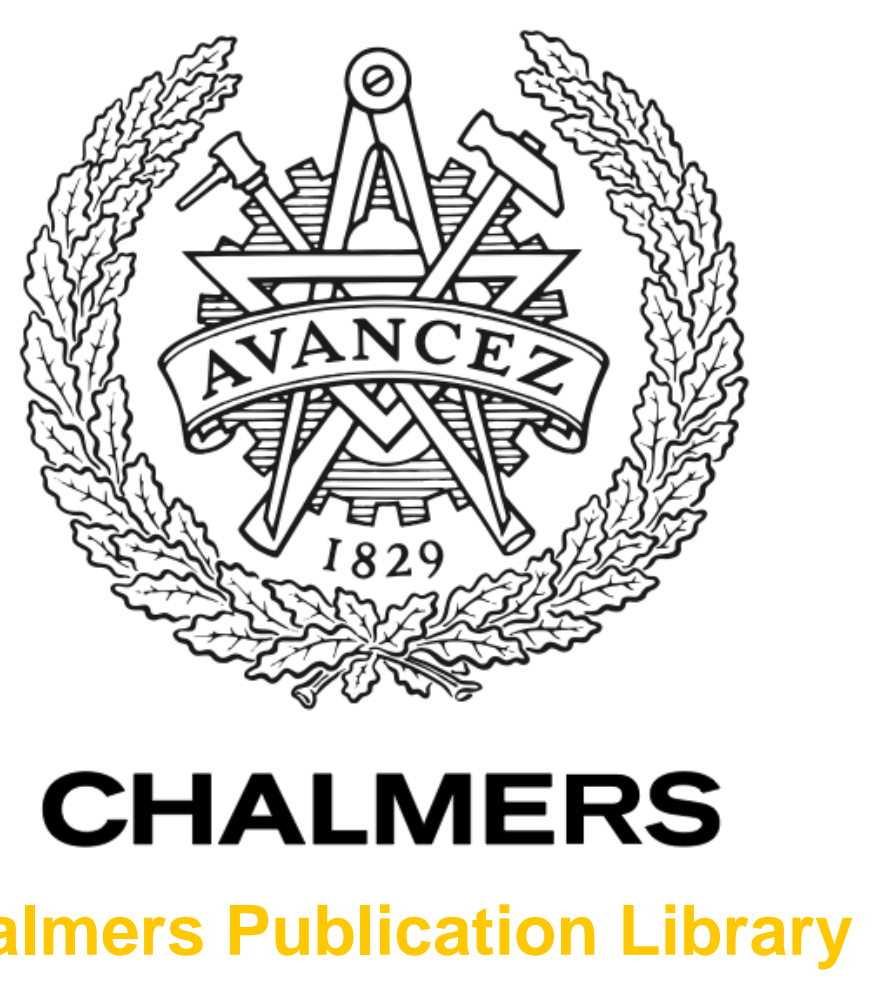

Chalmers Publication Library

\title{
Forces affecting one Lean Six Sigma adoption process
}

This document has been downloaded from Chalmers Publication Library (CPL). It is the author's version of a work that was accepted for publication in:

International Journal of Lean Six Sigma (ISSN: 2040-4166)

Citation for the published paper:

Assarlind, M. ; Aaboen, L. (2014) "Forces affecting one Lean Six Sigma adoption process". International Journal of Lean Six Sigma, vol. 5(3), pp. 324-340.

http://dx.doi.org/10.1108/IJLSS-07-2013-0039

Downloaded from: http://publications.lib.chalmers.se/publication/195135

Notice: Changes introduced as a result of publishing processes such as copy-editing and formatting may not be reflected in this document. For a definitive version of this work, please refer to the published source. Please note that access to the published version might require a subscription.

Chalmers Publication Library (CPL) offers the possibility of retrieving research publications produced at Chalmers University of Technology. It covers all types of publications: articles, dissertations, licentiate theses, masters theses, conference papers, reports etc. Since 2006 it is the official tool for Chalmers official publication statistics. To ensure that Chalmers research results are disseminated as widely as possible, an Open Access Policy has been adopted.

The CPL service is administrated and maintained by Chalmers Library. 


\title{
Forces affecting one Lean Six Sigma adoption process
}

\author{
Marcus Assarlind*, marcus.assarlind@chalmers.se \\ Division of Quality Sciences, Chalmers University of Technology \\ Lise Aaboen, lise.aaboen@iot.ntnu.no \\ Norwegian University of Science and Technology (NTNU)
}

"This article is (C) Emerald Group Publishing and permission has been granted for this version to appear at Chalmers publication library. Emerald does not grant permission for this article to be further copied/distributed or hosted elsewhere without the express permission from Emerald Group Publishing Limited."

\section{Purpose}

The purpose of this paper is to identify forces (in the form of converters and inhibitors) of Lean Six Sigma adoption by studying the gradual adoption of Lean Six Sigma in a medium-sized Swedish manufacturing company. The paper suggests how the converters and inhibitors interact toward increased maturity or stagnation of adoption.

\section{Design/Methodology/Approach}

Thirteen interviews were recorded and analyzed to identify converters that were moving the process forward or backward, as well as inhibitors that caused it to linger.

\section{Findings}

It was discovered that activities that had initially moved the process forward were not sufficient to move it beyond its current point. However, an increased knowledge of Lean Six Sigma throughout the organization now prevents the process from moving in the opposite direction. In this medium-sized Swedish manufacturing company, Lean Six Sigma becomes a framework for thought and communication during Lean work.

\section{Research Limitations/Implications}

The study benefited from considering forces pushing the process forward as well as backward. Thus, we suggest that future studies will benefit from focusing beyond critical success factors (CSFs) that may at times be static in nature. As a limitation, for discussions about the past, the memories of interviewees generally may have a tendency to be biased.

\section{Originality/Value}

The paper contributes knowledge of Lean Six Sigma adoptions and how they may attain greater future success by reporting on difficulties and setbacks in the current gradual adoption process in a chosen company. 
Keywords: Lean Six Sigma, adoption process, implementation, small and medium-sized enterprises, continuous improvements.

Article Classification: Research paper.

\section{Introduction}

With common roots in American industry and the quality revolution in the Japanese export industry, Lean Manufacturing and Six Sigma evolved as mainly separate concepts until the late 1990s and early 2000s (Dahlgaard and Dahlgaard-Park, 2006). Recently, the potential benefits of combining the two concepts have been observed (e.g. Arnheiter and Maleyeff, 2005; Assarlind et al., 2013). Lean Six Sigma has been defined by for instance Laureani and Antony (2012a, p. 110) as "a business improvement methodology that aims to maximize shareholders' value by improving quality, speed, customer satisfaction, and costs: it achieves this by merging tools and principles from both Lean and Six Sigma" even though other authors such as Gershon and Rajashekharaiah (2011, p. 27) point out that "leading texts fail to define Lean Six Sigma as a unique methodology". Other experts maintain that the Lean Six Sigma combination is not new but rather that "the most advanced applications of lean systems in Japan rely on the use of 'production engineers', whose training is an equivalent of the Six Sigma Black Belt" (Antony, 2011, p. 188). Laureani and Antony (2012a, p. 275) outline the general idea by stating that "Lean Six Sigma uses tools from both toolboxes in order to get the best from the two methodologies, increasing speed while also increasing accuracy". Both Lean and Six Sigma require a company to focus on its products and customers since according to Stoiljković et al. (2011), the concepts are intertwined in that Lean speed enables Six Sigma quality and Six Sigma quality enables Lean speed.

Research on "Lean Six Sigma" is limited and Pepper and Spedding (2010) state that no standard framework for such a combination exists. Pepper and Spedding (2010) as well as Ferng and Price (2005) similarly point out that Lean thinking may be used to identify areas of improvement and set standards, while the Six Sigma methodology may be used for targeting them and for investigating deviations from said standards. Hoerl (2004) on the other hand recommends basing Lean Six Sigma on Six Sigma while utilizing Lean ideas during the Analyze phase. Assarlind et al. (2013) identify yet another combination in which improvement teams and methods similar to Lean are used for smaller projects while the Six Sigma improvement structure Define, Measure, Analyze, Improve, Control (DMAIC), the hierarchy of improvement competency (Belt structure) and improvement methods are used for larger projects. Hilton and Sohal (2012) maintain that the important distinguishing feature of a Lean Six Sigma company is that it allows Black Belts to run projects according to the DMAIC structure, utilizing various statistical and Lean tools. However, Laureani and Antony (2012b) point out that no standard certification for roles in the Lean Six Sigma Belt structure exists. Gershon and Rajashekharaiah (2011) maintain that the major appeal of Lean Six Sigma to industry might be that the Lean component ensures faster, cheaper and more visible results compared to Six Sigma and therefore recommend that initial Lean Six Sigma projects be used as first steps towards a Six Sigma structure that would have a lasting impact on improvement efforts. While Lean tools ensure quick results and early 
engagement from staff, Six Sigma delivers superior bottom-line results from improvements. When deployed simultaneously, Lean and Six Sigma help to engage all types of people in improvement activities so that organizations become truly capable and attain competitive advantage (Antony, 2011, p. 189).

SMEs are firms with less than 250 employees (European Commission, 2005). Important SME characteristics (Hollander, 1967) include that they are business that include the business functions and decisions regarding production, financing, marketing and management as well as a personalized management (in contrast to institutionalized management). Empirically, early attempts to study Lean Six Sigma in SMEs (see for example Deshmukh and Chavan, 2012 for different definitions of SMEs worldwide) tend to use different frameworks and stepwise methodologies demonstrated in successful single projects (e.g. Gnanaraj et al., 2012; Kumar et al., 2006; Thomas et al., 2009; Wang and Chen, 2012). For instance, Franchetti and Barnala (2013) study a Lean Six Sigma implementation process at a recycling company; however, the activities that took place during the actual implementation of the improvements were not described. Prasanna and Vinodh (2013) conclude, from their literature review on Lean Six Sigma in SMEs, that literature on Lean Six Sigma in SMEs is scant. Based on Six Sigma and Lean separately, they develop a project model based on the Six Sigma DMAIC cycle, with added Lean aims and tools.

In order to contribute to the literature and practice of Lean Six Sigma adoption in mediumsized companies, the purpose of this paper is to identify forces (in the form of converters and inhibitors) of Lean Six Sigma adoption by studying the gradual adoption of Lean Six Sigma in a medium-sized Swedish manufacturing company. The research gap addressed by the present paper has several dimensions. First, most previous studies of the adoption of Lean Six Sigma report on projects that have already achieved success. The present paper reports instead on an adoption process that has not achieved unquestioned success. Second, even though SMEs are often suppliers to bigger companies and, therefore, need to have similar processes in place (Deshmukh and Chavan, 2012), studies of the practical applications of Lean Six Sigma have been mostly conducted in large companies. Another contribution by the present paper is therefore that it reports on a study of a medium-sized company. Third, most studies of practical applications take an ex-ante approach to the adoption process by reporting on a pre-decided project. The present paper, in contrast, takes an ex-post approach to the process of Lean Six Sigma adoption by studying the gradual and rather ad hoc process that led the company to an emerging Lean Six Sigma presence without its full-scale adoption. The principal author acted as an external mentor for three of the Six Sigma Black Belt projects carried out at PeakTech, a medium-sized Swedish manufacturing company (company name changed to provide anonymity). Through these projects, this author gained sufficient initial insight about the adoption process to be able to evaluate PeakTech as a company suitable for the present case study. In other words, PeakTech was selected because of its ability to provide insights that were unattainable in other organizations, as suggested by Siggelkow (2007). The adoption process at PeakTech is typical in that it contains both advancements and setbacks, all of which are analyzed in this paper. PeakTech operates in an industry in which certifications across multiple 
geographical markets are very important for business. Therefore, reports reflecting anything but operational excellence may potentially harm the company. As such, for the sake of anonymity, this paper reveals as little as possible about the context of the company, to avoid censorship of other parts of the case background.

\section{Theoretical Framework}

Lean is essentially a strategy to reach both flow efficiency and resource efficiency by prioritizing the former (Modig and Åhlström, 2012). The way to reach such a goal is said to be a mix of technical and managerial aspects, such as low inventories and operator driven improvement work (e.g. Krafcik, 1988; Liker, 2004; Womack et al., 1990). Assarlind et al. (2013) point out that some characteristics are often connected with Lean, for example, continuous improvement (Ricondo and Viles, 2005), consistent use of value stream mapping (Womack, 2006), employee involvement (Holbeche, 1998) and the aim to remove waste (Näslund, 2008).

Similarly, characteristics often connected with Six Sigma include the Define, Measure, Analyze, Improve, Control (DMAIC) project structure (Hoerl, 2004), quality and statistical tools (Magnusson et al., 2003; Mitra, 2004), considerable customer focus (Bergman and Klefsjö, 2010), fact-based decision-making (Goh and Xie, 2004), a focus on bottom-line results (Goh, 2002), and the aim to reduce process variation (Näslund, 2008). In their attempt at a definition, Schroeder et al. (2008, p. 540) state that "Six Sigma is an organized, parallel-meso structure to reduce variation in organizational processes by using improvement specialists, a structured method, and performance metrics for the purpose of achieving strategic objectives"; thus including all aforementioned characteristics except customer focus, which is replaced by the more generic "strategic objectives". In the context of large firms, there are several studies of the implementation of Six Sigma (e.g. Coronado and Antony, 2002; Kwak and Anbari, 2006; Pyzdek, 2003). Similarly to Lean, Six Sigma contains strong fluxes of improvement work; however, these activities within a Six Sigma context are often statistical and driven by experts and specialists through what are known as "Belt" structures. According to Laureani and Antony (2012b), an important difference between Six Sigma and Lean Six Sigma is that while the responsibility for Six Sigma is often limited to the production floor and statisticians in the quality department, Lean Six Sigma introduces quality implementation roles that can be used throughout an organization.

The notion of "process" possesses a myriad of different meanings in the literature, for example "a network of interrelated activities that are repeated in time, whose objectives is to create value to external or internal customers" (Bergman and Klefsjö, 2010, p. 42). In this paper, however, process is used to describe "a sequence of events or activities that show how things change over time" (van de Ven, 1992, p. 170). Following this definition, when we study a process, we examine "how events come into being and unfold over time in a context" (Halinen et al., 2012, p. 215). To better discuss such change, van de Ven and Poole (1995) conceptualize unit and mode of change, which are supplemented by Weick and Quinn (1999) with speed of change, the latter being either episodic or continuous. While both types allow for continuous adaptation, in episodic change, such adaptation is created by a change agent (Pinedo-Cuenca et al., 2012). 
In studies of the adoption of Six Sigma, Lean and Lean Six Sigma, it is common to identify critical success factors (CSFs) (Chakraborty and Chuan, 2013). However, the existence of a wealth of CSFs may be seen as an indication of theoretical confusion which is why these factors should be applied to real-life situations to verify their existence (Ismyrlis and Moschidis, 2013). Furthermore, the study of Bhasin (2013, p. 129) "proved that in the highest performing organizations, that [sic] the Lean barriers are either not permitted to cultivate and/or do not prevent the organization from advancing on its Lean journey". Hence, it may be precarious to study CSFs in isolation without taking into account context and current situation. Previous studies also provide examples of factors that are important during different phases of an adoption process. For example, Pinedo-Cuenca et al. (2012) structure their many success as well as hindering factors for the adoption of Six Sigma in SMEs into three sequential organizational change stages, unfreeze, move and freeze. However, in contrast, the present paper does not consider these factors to be statically connected to a certain phase but rather to be potentially present in all phases, i.e. as potentially providing different energies to the process depending on the current status of the process and organization.

A few previous studies focus on factors that influence the adoption of Lean Six Sigma in SMEs (e.g. Psychogios and Tsironis, 2012; Timans et al., 2012). Using samples of Dutch manufacturing SMEs and medium-sized Eastern European airlines, the studies identify success factors and impeding factors/barriers to improvements. In the setting of process improvements, Bateman and Rich (2003) and Garcia-Sabater et al. (2012) used the terms "enablers" and "inhibitors" to denote strengths and barriers to continuous improvement when studying British and Spanish automotive component manufacturers. These definitions have in common the assumption that factors influence a process that can only move in one direction - forward. However, Sørensen et al. (2010) and Assarlind (2010) point out that processes tend to be more complex, disorderly and interactive than what may be visible in simple presentations of consecutive development stages.

The adoption of a concept, such as Lean Six Sigma, does not appear to be binary; instead it places an organization on a journey. To address this fact and distinguish between different maturity stages during the adoption of improvement systems, Bessant and Caffyn (1997) developed a maturity level index. In this paper, an adaptation of this work, refined in Bessant and Francis (1999), as well as Chapman and Hyland (2000), was used. This adapted index encompasses different levels - Randomness, Trying Out, Structured, Strategic, Empowered, and Learning Organization - thus ranging from little or no activity to making the initiative an integral part of a company, see Table 1. 
Table 1 - Operations improvement maturity level (adapted from Bessant and Caffyn, 1997; Bessant and Francis, 1999; Chapman and Hyland, 2000)

\begin{tabular}{|c|c|c|}
\hline Level & Description & Typical characteristics \\
\hline $\mathbf{0}$ & Randomness & $\begin{array}{l}\text { Random, no formal efforts, occasional bursts of activity punctuated by } \\
\text { inactivity. }\end{array}$ \\
\hline 1 & Trying out & $\begin{array}{l}\text { Occurs due to special problem, inspiration from training intervention. } \\
\text { Often local and short-lived. }\end{array}$ \\
\hline 2 & Structured & Formal attempts, some training, not yet integrated into company strategy. \\
\hline 3 & Strategic & Efforts connected to strategic goals, measuring against these goals. \\
\hline 4 & Empowered & $\begin{array}{l}\text { Top-down focus complemented by bottom-up actions as emerging } \\
\text { strategic processes }\end{array}$ \\
\hline 5 & Learning organization & Sharing of learning; "how we do business around here". \\
\hline
\end{tabular}

Intrinsically, a journey from level 0 to level 5 does not happen swiftly. For example, moving to level 2 would further require a systematic approach to problem localizing and problem solving behaviors (Bessant and Francis, 1999; Imai, 1986), and level 3 would not only require a focused management, but also strong co-operation across corporate divisions (Bessant and Caffyn, 1997). The highest levels include a systematic approach to process improvement (Bessant and Caffyn, 1997), i.e. an organization can improve gradually but can never be "finished" with the adoption of certain process improvements.

When identifying factors during the adoption process, we therefore use the framework conceived by Edvardsson et al. (2008) that acknowledges that the process can move both forward and backward. In the model by Edvardsson et al. (2008), a process may start, pause or end at any status, as well as moving between statuses. The framework thereby takes into account that a process may be more complex, disorderly and interactive than what may be visible during consecutive stages. Furthermore, "converters" and "inhibitors" explain the movement between the different levels in Table 1. Converters provide energy for moving forward or backward among the statuses, while inhibitors prevent any change (backward or forward), thereby causing the process to linger (Edvardsson et al., 2008). In other words, a converter forward provides energy for moving from a lower level of maturity to a higher level, while a converter backward provides energy for moving from a higher level of maturity to a lower level. Conversely, an inhibitor forward provides energy for preventing the adoption process from moving from a lower level of maturity to a higher level of maturity, while an inhibitor backward provides energy for preventing the process from moving from a higher level of maturity to a lower level. In an ideal scenario, a successful adoption process benefits from several converters forward and inhibitors backward, so that the organization moves toward a higher level of maturity, with small risk of moving backwards towards lower levels, should the process run into problems. However, each converter and inhibitor is only a force providing the energy. An actual change in the level of maturity is the product of a combination of several converters and inhibitors. Edvardsson et al. (2008) emphasized that the converters and inhibitors are analytical tools and should not be studied or applied mathematically. The adoption thus becomes an iterative process, 
"with each iteration hopefully advancing the adoption process and the maturity of an organization" (Assarlind, 2014, p. 42). However, as suggested by the Edvardsson et al. (2008) framework, iteration may cause adoption to both advance as well as regress. When identifying factors, the context and current situation during the process are taken into account, which allows for the possibility that the energy from the converters and inhibitors may contribute differently during different phases of the adoption process. It is not the factor in and of itself that is important, but the kind of energy it infuses into the process. Based on this framework, we are able to formulate three research questions:

- What converters may be found during the Lean Six Sigma adoption process at PeakTech?

- What inhibitors may be found during the Lean Six Sigma adoption process at PeakTech?

- How have converters and inhibitors contributed to the Lean Six Sigma adoption process at PeakTech?

\section{Data Collection and Analysis}

This paper reports on the adoption of Lean Six Sigma at PeakTech. The choice of this particular single case was based on reading three Black Belt project reports, as well as observations made during the process of carrying out these Black Belt projects. The reports and observations also provided indications of the functions performed by potential interviewees, as well as themes for our interview guides. It soon became evident that the leading actor during the adoption process was the improvement expert; consequently, our first interview was held with this individual and the second interview with the production manager who might be said to have initiated the process.

The initial interviews were combined with a number of informal interviews carried out during 2010 and 2011. These interviews were focused on the history of PeakTech, the reasons for initiating the adoption and the activities carried out at that time. In order to capture the process throughout the company, the interviews were carried out during 2012 and included employees from top management to operator level in the manufacturing, product development, and IT departments. Besides all relevant department managers, about half of the remaining interviews were proposed by the production manager and the improvement expert, while the rest were randomly chosen to avoid potential bias. At the end of the study, follow-up interviews were made with the manager and the improvement expert. During these interviews, the events that had taken place in the process since the last interview were discussed. It also became possible to inquire in detail regarding topics that had been raised during remaining interviews. In order to increase the willingness of other employees to speak freely, their identities would not be revealed. To some degree, this longitudinal perspective counteracted the problem of interviewees preferring to tell what they remembered as opposed to what actually happened, as discussed by Hoholm and Araujo (2011).

In total, 13 recorded interviews were carried out by the principal author. After transcription, the first step of the analysis was data reduction (Miles and Huberman, 1994) during which 
the meaning condensed transcripts (see further Kvale and Brinkmann, 2009), reports and field notes based on observations were compiled. Based on the compilation of these data, an empirical description of the case was prepared. At this point triangulation was used to expand the dataset rather than for verification (Flick, 2006). An initial managerial evaluation was presented at a meeting with the senior management of PeakTech. Notes were taken and discussion comments were added to our data, serving both as new information and as information contributing to triangulation by using multiple sources of information (Voss et al., 2002), and verification of existing information. The revised dataset was analyzed in order to prepare a draft of the present paper. Data were chronologically arranged and all event episodes that seemed to be related to converters or inhibitors were underlined. Underlined events and episodes were then grouped together according to the converter or inhibitor described. In other words, analysis was performed continuously (as suggested by Lee, 1999). The analysis of the single PeakTech case study provided insights into the ongoing adoption process of Lean Six Sigma, from which we were able to report on successes and advancements, as well as difficulties and setbacks ${ }^{1}$.

\section{The Gradual Adoption of Lean Six Sigma at PeakTech}

PeakTech is a medium-sized high technology company in an industry characterized by the demands of meeting rules and certifications. PeakTech was founded in 1999 based on a research invention suitable for commercialization. The company was organized as a startup until it was bought in 2005 by its current owners, a multinational company. The current owners allow PeakTech to develop as a separate entity. Between 2005 and 2012, the company grew from about 65 employees and sales of $€ 20$ million to about 200 employees and sales of $€ 70$ million. Today, the company ships about 20,000 units yearly, manufactured on one production line.

\subsection{The starting point of the gradual adoption}

In 2006, there were no direct competitors on the market, and PeakTech became exceedingly profitable. The CEO wished to increase output which led to the hiring of a new production manager from the automotive industry. This manager noticed that a large share of the products shipped was returned for repair during the first year and that within two years of delivery, a majority of the products shipped were returned for repair. At that time, about five employees were dedicated to handling repairs and quality issues and PeakTech had expansion plans for doubling the company within three years.

\subsection{The early search for suitable approach}

The new production manager started to search for ways to improve the organization. Since PeakTech had historically been a research-based company, there was a corporate tradition of continuing education. In 2006, many of the courses available on the market were related to Lean; as a result, the manager started having middle managers within the production department attend a five weeks Lean course at a technical university. The manager himself

${ }^{1}$ The authors are indebted to the anonymous reviewers for pointing out this aspect as original and critical for this paper. 
attended this course the following year and during breaks, he started to talk to one of the teachers (the "improvement expert"). In 2008, PeakTech was temporarily banned from an important geographical market that had normally constituted one-third of total sales over several months due to its failure to correctly document the production processes of its products. The production manager dedicated a great deal of resources in order to quickly carry out the necessary improvements. The improvement expert was hired as a consultant to assist with problem-solving, mostly technical with a large portion of statistical methods, to alleviate the situation. In 2009, the improvement expert was brought on-board as an employee to organize some systematic improvement efforts across the entire organization. The production manager recruited several former colleagues from the automotive industry while PeakTech was also hiring several employees from a large Swedish car manufacturer in order to increase the number of company employees accustomed to working in a structured manner.

\subsection{The early trials of new methods}

During interviews, the improvement expert maintained that he wanted to avoid using a standard toolbox by instead identifying issues in the organization and then approaching problems with the help of suitable methodologies from Lean, Six Sigma, Robust Design Methodology (e.g. Arvidsson and Gremyr, 2008) or Lean Product Development (e.g. Karlsson and Åhlström, 1996). Due to the problems of variation in production, the ideas behind Six Sigma were considered appropriate for the company. "Six Sigma is also a nice buzzword in that context. People may recognize it." These early improvement efforts in production resulted in a paced one-piece flow. Within development, Robust Design Methodology became the preferred methodology because it was considered suitable in order to prevent quality problems in future products. To increase the awareness of these methodologies among the employees, PeakTech started to organize Green Belt courses for both white and blue collar workers to get the process off-the-ground. Since PeakTech was a growth company, employees were accustomed to change and had an "OK, guess we can try it" attitude to the suggested improvements. The improvement expert moved to another department in order to increase his ability to work across department boundaries at the same time as PeakTech Operational Excellence (OE) was launched as an umbrella for the operations improvement initiative. In 2011, even though its increase in sales had started to stagnate due to competitors entering the market, PeakTech had doubled its sales over three years and tripled its sales over five years.

\subsection{The current education activities}

In 2012, 15 corporate managers had attended the 7.5 ECTS Lean course at the technical university, 40-50 employees had completed the in-house Green Belt course and about 10 of them had also attended a Black Belt course organized by a certified external course provider. In addition, some employees had attended these courses before reporting to work at PeakTech. Employees who had completed this education could be found in most departments except for senior management.

Several interviewees who had attended the courses mentioned that there were no opportunities for following up on their respective project conducted as part of the course. Several employees mentioned that before or after taking the course, there were no 
discussions in their department as to how this new knowledge might be utilized. Some previous course participants felt disappointed when their enthusiasm for improvements could not be translated into practice once the course had been completed. It was mentioned that the lack of experience in conducting improvement projects made interviewees feel insecure about their abilities, which in turn discouraged them from initiating improvement projects of their own.

However, several previous course participants agreed that the courses had increased their knowledge of Lean Six Sigma and even though it was not visible in forms, presentation structures or other explicit modes of communication, it established an in-house vocabulary to be used as a common ground for discussions. For example, if someone were to suggest a Designed Experiment (e.g. Box et al., 2005), most people would now understand its meaning. The improvement expert hoped that the inspiring tools from the course that were now used in everyday work would engender an organizational culture where decisions were based on facts rather than on "shooting from the hip".

\subsection{The current organization}

In 2012, the competition had increased, the annual growth was down to five percent and PeakTech had stopped recruiting new employees. The percentage of repairs was still roughly the same as when the adoption process had started. This is uncommon in Lean Six Sigma implementation. However, since the products had become more advanced and complex during the same period, this development was nevertheless viewed as a relative improvement. Several interviewees maintained that repairs stemmed from "new" problems, while the "old" problems were now solved by improved production processes, often enhanced by using Design of Experiments. However, results were not communicated to the organization in any systematic way. Furthermore, the first completely redesigned products after $\mathrm{OE}$ had been instituted had yet to reach mass production.

Although the vocabulary in many parts of the organization had become inspired by Lean Six Sigma, the work was most clearly visible in the production area. It was possible to see people perform Design of Experiments and Gauge R\&R (similar to DoE, GR\&R is a statistical tool often connected to six Sigma, see also e.g. Burdick et al., 2005) with features of the IT system supporting these processes. Simultaneously, interviewees saw changes in attitudes: for example, "previously people did not care about attending FMEA meetings, now nobody is skipping them" (e.g. Stamatis, 2003 on FMEA).

The managers interviewed saw the work of the improvement expert as one part, albeit a major part, of the palpable OE initiative. In contrast, several non-management interviewees were not familiar with PeakTech Operational Excellence and viewed systematic improvement activities as synonymous with the improvement expert. By mid-2012, the improvement expert was given a cross-disciplinary mandate. However, there was a perception among employees that it was difficult for the improvement expert to get the full attention of senior management. The improvement expert believed that the initiative could benefit from additional resources allocated to training employees in Lean and Six Sigma techniques to help mentor, drive, and communicate OE. 
Interviewees who used to work in large automotive companies observed a great difference in the degree to which activities in the organization were integrated compared to their previous employer. Observations made during their time at PeakTech included "employed process developers that are used for other tasks", "the CEO handing out diplomas that nobody understood what they were for", and "projects only starting reactively based on complaints rather than being proactive". An interviewee discussed how ideas were gathered inside the organization. There had been some isolated initiatives, for example one department had tried to introduce an "improvement wheel" which was seen as "a good idea but it disappeared after one meeting". On another occasion, management had introduced a scheme of monetary rewards for improvement ideas, which was perceived as strange by interviewees.

\section{Discussion of the Roles of Converters and Inhibitors in the Adoption Process}

Converters and inhibitors identified in the empirical description above are summarized in Table 2 below. As explained at the end of the theoretical framework, a converter forward provides energy for moving from a lower level of maturity to a higher level, while a converter backward provides energy for moving from a higher level of maturity to a lower level. Conversely, an inhibitor forward provides energy for preventing the adoption process from moving from a lower level of maturity to a higher level of maturity, while an inhibitor backward provides energy for preventing the process from moving from a higher level of maturity to a lower level.

Before the Lean Six Sigma initiative was launched at PeakTech, the previous colleagues recruited by the new manager from the automotive industry applied their knowledge of Lean. However, this knowledge sharing only happened in occasional bursts, resembling maturity level 0 ("Randomness"; see Table 1). At the beginning of the process (see Table 2 ), several converters pushing the process forward were identified. Propelled by the combined forces of habitually sending employees to courses, meeting with an improvement expert, and becoming temporarily banned from an important geographical market, PeakTech moved to level 1 ("Trying Out"). Based on the decision to establish a formal initiative, hiring an in-house improvement expert and offering employee training, the process moved to level 2 ("Structured"). The fact that many employees had now attended various courses served as an inhibitor, preventing the process from moving backward. However, thanks to inhibitors preventing the process from moving forward and converters trying to force the process backwards, the process stagnated at level 2. Such forces included a lack of follow-up and utilization of completed projects, a lack of communication of results, a lack of visibility in formal systems, and the fact that no member of senior management knew how to support the process. As established by Gershon and Rajashekharaiah (2011), a major reason for combining Lean and Six Sigma is the quick results that may engage the staff. In that light, the failure to communicate the outcome of improvements is a serious inhibitor forward. 
Table 2 - Forces affecting the gradual adoption of Lean Six Sigma at PeakTech

\begin{tabular}{|c|c|c|c|c|}
\hline Force & $\begin{array}{c}\text { Converter } \\
\text { forward }\end{array}$ & $\begin{array}{l}\text { Inhibitor } \\
\text { backward }\end{array}$ & Inhibitor forward & $\begin{array}{l}\text { Converter } \\
\text { backward }\end{array}$ \\
\hline $\begin{array}{l}\text { Production manager } \\
\text { with experience from } \\
\text { the automotive } \\
\text { industry }\end{array}$ & $\begin{array}{l}\text { Detected potential } \\
\text { problem early }\end{array}$ & & & \\
\hline $\begin{array}{l}\text { Tradition of sending } \\
\text { employees to courses }\end{array}$ & $\begin{array}{c}\text { Knowledge and } \\
\text { networking }\end{array}$ & & & \\
\hline $\begin{array}{l}\text { Becoming temporarily } \\
\text { banned from an } \\
\text { important } \\
\text { geographical market }\end{array}$ & Awareness of need & & & \\
\hline $\begin{array}{l}\text { Hiring improvement } \\
\text { expert }\end{array}$ & $\begin{array}{c}\text { Individual that } \\
\text { drives the initiative }\end{array}$ & & $\begin{array}{l}\text { Not everyone's } \\
\text { responsibility }\end{array}$ & \\
\hline Offering GB courses & $\begin{array}{c}\text { Knowledge and } \\
\text { projects }\end{array}$ & & & \\
\hline $\begin{array}{l}\text { Moving improvement } \\
\text { expert to cross- } \\
\text { organizational } \\
\text { department }\end{array}$ & $\begin{array}{l}\text { Work more easily } \\
\text { across boundaries, } \\
\text { signals that it is } \\
\text { important to all } \\
\text { depts. }\end{array}$ & & & \\
\hline $\begin{array}{l}\text { Strong growth of } \\
\text { PeakTech until } 2011\end{array}$ & Available funding & & & $\begin{array}{c}\text { Sales and immediate } \\
\text { output prioritized }\end{array}$ \\
\hline $\begin{array}{l}\text { Employees taken } \\
\text { many courses }\end{array}$ & $\begin{array}{l}\text { Knowledge in } \\
\text { methods and } \\
\text { projects }\end{array}$ & $\begin{array}{c}\text { Shared } \\
\text { vocabulary }\end{array}$ & & \\
\hline $\begin{array}{l}\text { Numerous successful } \\
\text { projects }\end{array}$ & $\begin{array}{c}\text { Common } \\
\text { perception of } \\
\text { successful projects }\end{array}$ & & & \\
\hline $\begin{array}{l}\text { No members of senior } \\
\text { management have } \\
\text { attended courses }\end{array}$ & & & $\begin{array}{c}\text { Seemingly } \\
\text { misdirected } \\
\text { management } \\
\text { behavior causes } \\
\text { confusion } \\
\end{array}$ & $\begin{array}{l}\text { Signals that it is not } \\
\text { prioritized }\end{array}$ \\
\hline $\begin{array}{l}\text { Projects are not } \\
\text { followed up by other } \\
\text { actions }\end{array}$ & & & $\begin{array}{c}\text { Potential from } \\
\text { projects not fully } \\
\text { realized }\end{array}$ & $\begin{array}{l}\text { Things may go back } \\
\text { to previous states }\end{array}$ \\
\hline $\begin{array}{l}\text { No further projects } \\
\text { outside courses }\end{array}$ & & & $\begin{array}{l}\text { Individuals do not } \\
\text { gain enough } \\
\text { confidence in } \\
\text { starting } \\
\text { improvements } \\
\end{array}$ & Knowledge lost again \\
\hline $\begin{array}{l}\text { Lack of explicit } \\
\text { structures }\end{array}$ & & & $\begin{array}{l}\text { Individuals do not } \\
\text { know how to } \\
\text { communicate } \\
\text { suggestions } \\
\end{array}$ & $\begin{array}{l}\text { Lack of clarity on } \\
\text { how to manage } \\
\text { improvements, i.e. } \\
\text { they do not happen }\end{array}$ \\
\hline $\begin{array}{l}\text { Increased market } \\
\text { competition }\end{array}$ & $\begin{array}{c}\text { Increases } \\
\text { awareness }\end{array}$ & & & \\
\hline $\begin{array}{l}\text { Lack of } \\
\text { communication of } \\
\text { results }\end{array}$ & & & $\begin{array}{l}\text { Does not produce } \\
\text { any drive or } \\
\text { motivation }\end{array}$ & \\
\hline
\end{tabular}


In order for the adoption process to move forward across the entire company, a greater number of employees would need to get involved by acquiring the ability to contribute to the process in terms of knowledge, structures and the time to conduct the necessary project work. However, senior management was unlikely to be able to complement the work of the improvement expert. Initially in the process, almost all actions taken by the improvement expert served as a converter to push the process forward, and by increasing the knowledge among the employees, his projects faced less resistance, which also served as a converter pushing the process forward. The process has now reached a status where the improvement expert, by his presence in the organization and the activities performed, has become an inhibitor who prevents the process from moving backward while simultaneously being unable to move the adoption process forward.

As mentioned initially, no standard for combining Lean and Six Sigma exists in the literature. At PeakTech, the OE umbrella covered both methodologies without any clear-cut boundaries. The employees had taken Lean as well as Black Belt courses. Some employees had experienced previous Lean work in the automotive industry while others, for instance the improvement expert, had greater experience of Six Sigma. Different departments selected various tools appropriate for its work; by using both Lean and Six Sigma tools, a greater number of employees were able to contribute to the improvement work. In the empirical section of this paper, it becomes clear that Six Sigma tends to be the framework for thought and communication during Lean work at PeakTech. This view shows certain similarities to Gupta et al. (2012) who maintain that the Lean Six Sigma combination consists of the Six Sigma DMAIC structure in concert with the Lean philosophy. However, since the improvement expert was initially an expert of Six Sigma methodology and since many "Lean improvements" went into effect before the start of the formal Lean Six Sigma initiative, the focus on the Six Sigma vocabulary in the empirical section may give the impression that this paper deals with Six Sigma alone rather than with Lean Six Sigma. In the literature, it is possible to find examples of additional active Lean components in the adoption process, such as the utilization of "observation" at an airport in relation to Lean Six Sigma as described by Arumugam et al. (2012).

\section{Conclusion, limitations and future studies}

In this paper, we have examined the gradual adoption of Lean Six Sigma in a medium-sized Swedish manufacturing company and found that the adoption process in this case had stagnated. The purpose of the paper was to identify forces (in the form of converters and inhibitors) of Lean Six Sigma adoption by studying the gradual adoption of Lean Six Sigma in a medium-sized Swedish manufacturing company. The paper suggests how the converters and inhibitors interact to influence Lean Six Sigma adoption processes. The converters and inhibitors found in this case are summarized in Table 2. The results point to three main conclusions:

First, it is important to continually adjust the activities as the organization moves toward higher levels of maturity. Activities that acted as converters forward, pushing the organization from level 0 to level 1, and from level 1 to level 2, may no longer be sufficient to push the process forward from level 2 to level 3. The organization is different at this new 
level of maturity, and the forces of the converters will therefore have a different impact. Furthermore, the converters forward are interacting with different inhibitors forward and converters backward, from those with which they interacted previously.

Second, the adoption process at PeakTech demonstrates the necessity of acknowledging that a process of adoption can move both forward and backward. The activities associated with educating many employees, thereby creating a common language within an organization, are an important reason for why the process has simply stagnated without moving backward. Hence, companies seeking to adopt Lean Six Sigma should focus also on activities preventing the organization from backsliding.

Third, it is not the converters and inhibitors as such that are of interest, but rather how they contribute to the company's adoption process. For example, the importance of senior management participation in managing the adoption process is not inherently new. Habidin and Yusof (2013, p. 72) found the twin factors of leadership and customer focus to be "extremely important factors" for the adoption of Lean Six Sigma. Further, in their assessment of CSFs for Lean Six Sigma adoption, Laureani and Antony (2012a) identified management commitment and cultural change as the two top-ranked CSFs. In this paper, however, we show how management was actively inhibiting the adoption process from moving forward, and even pushing it backward.

One limitation of the research is that the analysis is based on interviews conducted during a limited period of time. Interviewees, when talking about past events, have a tendency to talk about the parts they prefer to remember, rather than what actually happened (Hoholm and Araujo, 2011). As such, interviewees may recall the beginning of the process as a time filled with events pushing the process forward, while forgetting other activities that happened simultaneously. As mentioned in the methods section, efforts were made to minimize this problem by conducting interviews at several points in time.

Another research limitation is that, because we do not yet have information on the rest of the adoption process, we do not know whether the identified stagnation is a permanent stagnation or a pause before moving backward or forward. Due to the often lengthy stages of contemplation, some stagnation should be expected in all change processes (Weick and Quinn, 1999). Despite this limitation, the paper has successfully identified how the converters and inhibitors have moved the process to the present state of stagnation, and how they interact to hinder the organization's further adoption of Lean Six Sigma. Practitioners and academics should be able to use these insights to better understand past, present, and future Lean Six Sigma adoption processes.

\section{References}

Antony, J. (2011), "Six Sigma vs Lean: Some perspectives from leading academics and practitioners", International Journal of Productivity and Performance Management, Vol. 60 No. 2, pp. 185-190.

Arnheiter, E. D. and Maleyeff, J. (2005), "The integration of lean management and Six Sigma", The TQM Magazine, Vol. 17 No. 1, pp. 5-18. 
Arumugam, V., Antony, J. and Douglas, A. (2012), "Observation: a Lean tool for improving the effectiveness of Lean Six Sigma", The TQM Journal, Vol. 24 No. 3, pp. $275-287$.

Arvidsson, M. and Gremyr, I. (2008), "Principles of robust design methodology", Quality and Reliability Engineering International, Vol. 24 No. 1, pp. 23-35.

Assarlind, M. (2010). "Exploring quality management implementation factors: In-depth study in one smaller company: "WashCo"". Paper presented at the 13th QMOD conference on Quality and Service Sciences. Cottbus.

Assarlind, M. (2014). Adoption of Quality Management in SMEs, Thesis for the degree of $\mathrm{PhD}$, Chalmers University of Technology, Gothenburg.

Assarlind, M., Gremyr, I. and Bäckman, K. (2013), "Multi-faceted views on a Lean Six Sigma application", International Journal of Quality \& Reliability Management, Vol. 30 No. 4, pp. 387-402.

Bateman, N. and Rich, N. (2003), "Companies' perceptions of inhibitors and enablers for process improvement activities", International Journal of Operations \& Production Management, Vol. 23 No. 2, pp. 185-199.

Bergman, B. and Klefsjö, B. (2010), Quality: From Customer Needs to Customer Satisfaction (3rd ed.), Studentlitteratur, Lund.

Bessant, J. and Caffyn, S. (1997), "High-involvement innovation through continuous improvement", International Journal of Technology Management, Vol. 14 No. 1, pp. 7-28.

Bessant, J. and Francis, D. (1999), "Developing strategic continuous improvement capability", International Journal of Operations \& Production Management, Vol. 19 No. 11, pp. 1106-1119.

Bhasin, S. (2013), "Impact of corporate culture on the adoption of the Lean principles", International Journal of Lean Six Sigma, Vol. 4 No. 2, pp. 118-140.

Box, G. E. P., Hunter, J. S. and Hunter, W. G. (2005), Statistics for Experimenters: Design, Innovation, and Discovery (2nd ed.), John Wiley and Sons, Hoboken.

Burdick, R. K., Borror, C. M. and Montgomery, D. C. (2005), Design and Analysis of Gauge R\&R Studies: Making Decisions With Confidence Intervals in Random and Mixed ANOVA Models, Society for Industrial and Applied Mathematics, Alexandria.

Chakraborty, A. and Chuan, T. K. (2013), "An empirical analysis on Six Sigma implementation in service organisations", International Journal of Lean Six Sigma, Vol. 4 No. 2, pp. 141-170.

Chapman, R. and Hyland, P. (2000), "Strategy and continuous improvement in small-tomedium Australian manufacturers", Integrated Manufacturing Systems, Vol. 11 No. 3, pp. 171-179.

Coronado, R. B. and Antony, J. (2002), "Critical success factors for the successful implementation of six sigma projects in organisations", The TQM Magazine, Vol. 14 No. 2, pp. 92-99.

Dahlgaard, J. J. and Dahlgaard-Park, S. M. (2006), "Lean production, Six Sigma quality, TQM and company culture", The TQM Magazine, Vol. 18 No. 3, pp. 263-281.

Deshmukh, S. V. and Chavan, A. (2012), "Six Sigma and SMEs: a critical review of literature", International Journal of Lean Six Sigma, Vol. 3 No. 2, pp. 157-167. 
Edvardsson, B., Holmlund, M. and Strandvik, T. (2008), "Initiation of business relationships in service-dominant settings", Industrial Marketing Management, Vol. 37 No. 3, pp. 339-350.

European Commission, (2005), "The new SME definition: User guide and model declaration", (NB-60-04-773-EN-C), available at: http://bookshop.europa.eu/en/thenew-sme-definition-pbNB6004773/ (accessed

Ferng, J. and Price, A. D. F. (2005), "An exploration of the synergies between Six Sigma, total quality management, lean construction and sustainable construction", International Journal of Six Sigma and Competitive Advantage, Vol. 1 No. 2, pp. 167-187.

Flick, U. (2006), An Introduction to Qualitative Research, Sage Publications, London.

Franchetti, M. and Barnala, P. (2013), "Lean Six Sigma at a material recovery facility: A case study", International Journal of Lean Six Sigma, Vol. 4 No. 3, pp. 2-2.

Garcia-Sabater, J. J., Marin-Garcia, J. A. and Perello-Marin, M. R. (2012), "Is implementation of continuous improvement possible? An evolutionary model of enablers and inhibitors", Human Factors and Ergonomics in Manufacturing \& Service Industries, Vol. 22 No. 2, pp. 99-112.

Gershon, M. and Rajashekharaiah, J. (2011), "Double LEAN Six Sigma - A Structure for Applying Lean Six Sigma", The Journal of Applied Business and Economics, Vol. 12 No. 6, pp. 26-31.

Gnanaraj, S. M., Devadasan, S. R., Murugesh, R. and Sreenivasa, C. G. (2012), "Sensitisation of SMEs towards the implementation of Lean Six Sigma - An initialisation in a cylinder frames manufacturing Indian SME", Production Planning \& Control, Vol. 23 No. 8, pp. 599-608.

Goh, T. N. (2002), "A strategic assessment of six sigma", Quality and Reliability Engineering International, Vol. 18 No. 5, pp. 403-410.

Goh, T. N. and Xie, M. (2004), "Improving on the six sigma paradigm", The TQM Magazine, Vol. 16 No. 4, pp. 235-240.

Gupta, V., Acharya, P. and Patwardhan, M. (2012), "Monitoring quality goals through lean Six-Sigma insures competitiveness", International Journal of Productivity and Performance Management, Vol. 61 No. 2, pp. 194-203.

Habidin, N. F. and Yusof, S. r. M. (2013), "Critical success factors of Lean Six Sigma for the Malaysian automotive industry", International Journal of Lean Six Sigma, Vol. 4 No. 1 , pp. 60-82.

Halinen, A., Medlin, C. J. and Törnroos, J.-A. (2012), "Time and process in business network research", Industrial Marketing Management, Vol. 41 No. 2, pp. 215-223.

Hilton, R. J. and Sohal, A. (2012), "A conceptual model for the successful deployment of Lean Six Sigma", International Journal of Quality \& Reliability Management, Vol. 29 No. 1, pp. 54-70.

Hoerl, R. (2004), "One perspective on the future of Six-Sigma", International Journal of Six Sigma and Competitive Advantage, Vol. 1 No. 1, pp. 112-119.

Hoholm, T. and Araujo, L. (2011), "Studying innovation processes in real-time: The promises and challenges of ethnography", Industrial Marketing Management, Vol. 40 No. 6, pp. 933-939. 
Holbeche, L. (1998), Motivating People in Lean Organizations, Butterworth-Heinemann, Oxford.

Hollander, E. D. (1967), The Future of Small Business, Frederick A Praeger, New York.

Imai, M. (1986), Kaizen: The key to Japan's competitive success, McGraw-Hill, New York, NY.

Ismyrlis, V. and Moschidis, O. (2013), "Six Sigma's critical success factors and toolbox", International Journal of Lean Six Sigma, Vol. 4 No. 2, pp. 108-117.

Karlsson, C. and Åhlström, P. (1996), "The difficult path to lean product development", Journal of Product Innovation Management, Vol. 13 No. 4, pp. 283-295.

Krafcik, J. F. (1988), "Triumph Of The Lean Production System", Sloan Management Review, Vol. 30 No. 1, pp. 41-52.

Kumar, M., Antony, J., Singh, R. K., Tiwari, M. K. and Perry, D. (2006), "Implementing the Lean Sigma framework in an Indian SME: a case study", Production Planning \& Control, Vol. 17 No. 4, pp. 407-423.

Kwak, Y. H. and Anbari, F. T. (2006), "Benefits, obstacles, and future of six sigma approach", Technovation, Vol. 26 No. 5-6, pp. 708-715.

Kvale, S. and Brinkmann, S. (2009), Den Kvalitativa Forskningsintervjun (S.-E. Torhell, Trans. 2nd ed.), Studentlitteratur, Lund.

Laureani, A. and Antony, J. (2012a), "Critical success factors for the effective implementation of Lean Sigma: Results from an empirical study and agenda for future research", International Journal of Lean Six Sigma, Vol. 3 No. 4, pp. 274283.

Laureani, A. and Antony, J. (2012b), "Standards for Lean Six Sigma certification", International Journal of Productivity and Performance Management, Vol. 61 No. 1, pp. 110-120.

Lee, T. W. (1999), Using Qualitative Methods in Organizational Research, Sage Publications, Thousand Oaks, CA.

Liker, J. K. (2004), The Toyota way: 14 Management Principles from the World's Greatest Manufacturer, McGraw-Hill, New York.

Magnusson, K., Kroslid, D. and Bergman, B. (2003), Six Sigma: The Pragmatic Approach (2nd ed.), Studentlitteratur, Lund.

Miles, M. B. and Huberman, A. M. (1994), Qualitative Data Analysis: An Expanded Sourcebook, Sage Publications, California.

Mitra, A. (2004), "Six sigma education: a critical role for academia", The TQM Magazine, Vol. 16 No. 4, pp. 293-302.

Modig, N. and Åhlström, P. (2012), This is Lean: Resolving the Efficiency Paradox, Rheologica Publishing, Halmstad.

Näslund, D. (2008), "Lean, six sigma and lean sigma: fads or real process improvement methods?", Business Process Management Journal, Vol. 14 No. 3, pp. 269-287.

Pepper, M. P. J. and Spedding, T. A. (2010), "The evolution of lean Six Sigma", International Journal of Quality \& Reliability Management, Vol. 27 No. 2, pp. 138155.

Pinedo-Cuenca, R., Olalla, P. G. and Setijono, D. (2012), "Linking Six Sigma's critical success/hindering factors and organizational change (development): A framework 
and a pilot study", International Journal of Lean Six Sigma, Vol. 3 No. 4, pp. 284298.

Prasanna, M. and Vinodh, S. (2013), "Lean Six Sigma in SMEs: an exploration through literature review", Journal of Engineering, Design and Technology, Vol. 11 No. 3, pp. 224-250.

Psychogios, A. G. and Tsironis, L. K. (2012), "Towards an integrated framework for Lean Six Sigma application: Lessons from the airline industry", Total Quality Management \& Business Excellence, Vol. 23 No. 3-4, pp. 397-415.

Pyzdek, T. (2003), The Six Sigma Handbook: A Complete Guide for Green Belts, Black Belts, and Managers at All Levels, McGraw-Hill, New York.

Ricondo, I. and Viles, E. (2005), "Six Sigma and its link to TQM, BPR, lean and the learning organisation", International Journal of Six Sigma and Competitive Advantage, Vol. 1 No. 3, pp. 323-354.

Schroeder, R. G., Linderman, K., Liedtke, C. and Choo, A. S. (2008), "Six Sigma: Definition and underlying theory", Journal of Operations Management, Vol. 26 No. 4, pp. 536-554.

Siggelkow, N. (2007), "Persuasion with case studies", Academy of Management Journal, Vol. 50 No. 1, pp. 20-24.

Stamatis, D. H. (2003), Failure Mode and Effect Analysis: FMEA from Theory to Execution (2nd ed.), ASQ Press, Milwaukee.

Stoiljković, V., Trajković, J. and Stoiljković, B. (2011), "Lean Six Sigma Sample Analysis Process in a Microbiology Laboratory", Journal of Medical Biochemistry, Vol. 30 No. 4, pp. 346-353.

Sørensen, F., Mattsson, J. and Sundbo, J. (2010), "Experimental methods in innovation research", Research Policy, Vol. 39 No. 3, pp. 313-322.

Thomas, A., Barton, R. and Chuke-Okafor, C. (2009), "Applying lean six sigma in a small engineering company - a model for change", Journal of Manufacturing Technology Management, Vol. 20 No. 1, pp. 113 - 129.

Timans, W., Antony, J., Ahaus, K. and Van Solingen, R. (2012), "Implementation of Lean Six Sigma in small-and medium-sized manufacturing enterprises in the Netherlands", Journal of the Operational Research Society, Vol. 63 No. 3, pp. 339353.

van de Ven, A. H. (1992), "Suggestions for studying strategy process: A research note", Strategic Management Journal, Vol. 13 No. S1, pp. 169-188.

van de Ven, A. H. and Poole, M. S. (1995), "Explaining development and change in organizations", The Academy of Management Review, Vol. 20 No. 3, pp. 510-540.

Wang, F.-K. and Chen, K.-S. (2012), "Application of Lean Six Sigma to a panel equipment manufacturer", Total Quality Management \& Business Excellence, Vol. 23 No. 3-4, pp. 417-429.

Weick, K. E. and Quinn, R. E. (1999), "Organizational change and development", Annual Review of Psychology, Vol. 50 No. 1, p. 361.

Womack, J. P. (2006), "Value stream mapping", Manufacturing Engineering, Vol. 136 No. 5, pp. 145-156.

Womack, J. P., Jones, D. T. and Roos, D. (1990), Machine that Changed the World, Simon $\&$ Schuster, New York. 
Voss, C., Tsikriktsis, N. and Frohlich, M. (2002), "Case research in operations management", International Journal of Operations \& Production Management, Vol. 22 No. 2, pp. 195-219. 